\title{
Industry 4.0: An analysis of the production of scientific papers based on indicators
}

\author{
Indústria 4.0: Uma análise da produção de trabalhos científicos a partir de indicadores \\ Industria 4.0: Un análisis de la producción de artículos científicos a partir de indicadores
}

Received: 07/30/2021 | Reviewed: 08/04/2021 | Accept: 08/27/2021 | Published: 08/28/2021

\author{
Maria do Socorro de Souza \\ ORCID: https://orcid.org/0000-0001-5793-0530 \\ Universidade Municipal de São Caetano do Sul, Brazil \\ E-mail: promariesouza@gmail.com \\ Jakeline Rodrigues de Aquino Bezerra \\ ORCID: https://orcid.org/0000-0002-8852-4217 \\ Universidade Municipal de São Caetano do Sul, Brazil \\ E-mail: jakelineraquino@hotmail.com \\ Luis Paulo Bresciani \\ ORCID: https://orcid.org/0000-0002-6028-4493 \\ Universidade Municipal de São Caetano do Sul, Brazil \\ E-mail: promariesouza@gmail.com \\ Edimilson Eduardo da Silva \\ ORCID: https://orcid.org/0000-0002-6104-7625 \\ Universidade Federal dos Vales do Jequitinhonha e Mucuri, Brazil \\ E-mail: edimilsones2013@gmail.com
}

\begin{abstract}
The application of technologies related to Industry 4.0 is already underway in countries such as the United States, Germany, China, South Korea and Japan. Given the importance of using new technologies of Industry 4.0, listed in the scientific literature, we aim to understand how international academic publications on Industry 4.0 are characterized, based on their scientific indicators. In order to meet the objective, scientific publications were extracted from the Web of Science platform and analysis techniques such as Bibliometric, Spearman Correlation and Clustering (Cluster) were used. The revelations have pointed out that the Industry 4.0 theme is recent in terms of scientific publications by the Web of Science platform. In this database, the first Management, Business and Economics academic publications took place in 2016, although from 2018 onwards, there is a significant increase of academic publications in the researched area. Empirical disclosure provided evidence that the various measurements of indicators on the Impact Factor and number of citations converge with each other. The results pointed to a gap in indicators that demonstrate academic publications with expressive citations in low-impact journals. Finally, it is pointed out that these quantitative disclosures contribute to the decision-making initial process, but with limitations, considering the importance of interpretive analysis of the scientific literature content.
\end{abstract}

Keywords: Industry 4.0; Indicators; Cluster.

\section{Resumo}

A aplicação de tecnologias relacionadas à Indústria 4.0 já está em curso em países como os Estados Unidos, Alemanha, China, Coréia do Sul e Japão. Diante da importância do uso de novas tecnologias da Indústria 4.0, elencadas pela literatura científica, este trabalho tem como objetivo compreender como estão caracterizadas as publicações internacionais sobre o tema Indústria 4.0, a partir de seus indicadores científicos. Com o intuito de atender ao objetivo, extraiu-se publicações científicas na plataforma Web of Science e utilizou-se técnicas de análise como a Bibliométrica, Correlação de Spearman e Agrupamento (Cluster). As revelações apontaram que o tema Indústria 4.0 é recente em termos de publicações pela plataforma Web of Science. Nessa base de dados, a primeira publicação nas áreas de Gestão, Negócios e Economia aconteceu no ano de 2016, embora, a partir de 2018, se evidencie um aumento significativo das publicações na área pesquisada. A revelação empírica forneceu evidências de que as várias medições dos indicadores de Fator de Impacto e número de citações, convergem entre si. Os resultados apontaram uma lacuna de indicadores que demonstrem publicações com expressivas citações em periódicos de baixo fator de impacto. Por fim, aponta-se que essas revelações quantitativas contribuem no processo inicial de tomada de decisão, mas com limitações, tendo em vista a importância da análise interpretativa dos conteúdos das publicações científicas.

Palavras-chave: Indústria 4.0; Indicadores; Cluster.

\section{Resumen}

La aplicación de tecnologías relacionadas con la Industria 4.0 ya está en marcha en países como Estados Unidos, Alemania, China, Corea del Sur y Japón. Dada la importancia del uso de las nuevas tecnologías de la Industria 4.0, 
recogidas por la literatura científica, este trabajo pretende conocer cómo se caracterizan las publicaciones internacionales sobre el tema Industria 4.0, a partir de sus indicadores científicos. Para cumplir el objetivo, se extrajeron las publicaciones científicas en la plataforma Web of Science y se utilizaron técnicas de análisis como la Bibliometría, la Correlación de Spearman y el Clustering. Las revelaciones señalan que el tema de la Industria 4.0 es reciente en cuanto a las publicaciones de la plataforma Web of Science. En esta base de datos, la primera publicación en las áreas de Gestión, Empresa y Economía se produjo en el año 2016, aunque, a partir de 2018, se evidencia un aumento significativo de publicaciones en el área investigada. La revelación empírica aportó pruebas de que las distintas medidas de los indicadores de Factor de Impacto y número de citas, convergen entre sí. Los resultados señalaron una brecha de indicadores que demuestran publicaciones con citas expresivas en revistas con bajo factor de impacto. Por último, se señala que estas revelaciones cuantitativas contribuyen al proceso inicial de toma de decisiones, pero con limitaciones, dada la importancia del análisis interpretativo de los contenidos de las publicaciones.

Palabras clave: Industria 4.0; Indicadores; Cluster.

\section{Introduction}

The dynamic of the globalization in manufacturing and services contributes to a change in competition patterns in national economies, at the same time that it questions institutional strategies, leading these economies to expand synergies with other social agents, with the goal of knowledge diversification and results-oriented cooperation (Christensen; Raynor; \& Mcdonald, 2015). In this sense, the elaboration of strategic plans that contribute to the efficiency and effectiveness of processes related to the delivery of products and services is necessary for companies in the various sectors of activity that constitute a local or global economy.

The last few years have been marked by technological changes that have greatly contributed for companies to remain in the competitive market, meeting the needs of their customers and being sustainable over time. These technological changes, also known as digital transformation, are related to an abrupt and radical change that modifies social structures, economic systems, and has already been adopted in industrial and commercial processes and in service delivery. These major changes are drivers of Industry 4.0, which is marked by the use of new technologies and new ways of perceiving the world (Schwab, 2018).

The application of technologies related to Industry 4.0 is already ongoing in countries like the United States, Germany, China, South Korea and Japan. These countries, which together with the government, have industrial policies, strategies and plans for the medium and long term, aimed at increasing productivity, reconfiguration of manufacturing plants, innovation and new tools that can train the workforce needed to operate in this new economic and social context (IEDI, 2017; Arbix, et al., 2017).

Given the above, and the importance of the new economic and industrial context deriving from the use of new Industry 4.0 technologies, it is pertinent to understand the main academic publications on the subject, with the impact indicators and the focus on the academic discussion.

In order to meet the objectives of this research, the following problem was formulated: How are international academic publications, on the topic Industry 4.0, characterized through their scientific indicators from 2011 to 2020 ?

The importance of investigating the subject is justified due to the evolution in the number of the academic articles published in recent years, which is related to changes from an organizational, academic, and social point of view. For the academia, this work will contribute with a more accurate analysis of articles published in thematic areas, for a decision-making by the researcher in assigning a certain value to the articles selected for future research, besides a discussion of what is being produced. From the business point of view, the work contributes to disseminating knowledge relevant to the topic, being an object of analysis for management decision-making.

For a better analysis and depth of research related to the topic, we investigated the citation metrics of the published articles, such as the impact factor and in which journals they are indexed. 
According to the research objective, this article is divided into five sections, considering this introduction. The following section will present the literature review referring to Industry 4.0, the quantitative analysis method of scientific research, Bibliometrics, followed by the main indicators used for the evaluation of scientific productions, such as the Impact Factor-FI, the H (h-index) and the Scimago Journal Rank-SJR.

\section{Literature Review}

The beginning of a research requires the researcher to thoroughly investigate a subject or theme of a given area. It is from the investigation that the various published works are assessed, classified and analysed in order to build knowledge, its production and application.

The evaluation of scientific papers is frequently conducted by means of indicators such as the number of citations and the impact factor of the journal in which an article is published. In this sense, it will be presented sections that list the Industry 4.0, some metrics of scientific production evaluation used by the academia and the Bibliometrics technique.

\subsection{Industry 4.0: a brief presentation}

The concept of Industry 4.0 was first used in 2011 in Germany to define the strategic initiative known as "Industry 4.0". This initiative was developed with government support and in partnership with universities and industries located in the country, and aimed to make Germany a pioneer country in the production and use of industrial information technology, thus revolutionising industrial production (IEDI, 2017).

In this new approach to industry, virtual and physical systems of manufacturing globally cooperate with each other in a flexible way. It stands out as fundamentally different the fusion of these technologies and their interaction across the physical, digital and biological domains involving the organization and the global value chain (Schwab, 2017, p.16).

Another industrial focus refers to the industry as the "Industrial Internet of Things" (IIoT) and refers to the integration of Internet of Things (IoT) technologies in the industrial sector, enabling the processes in factories being fully digitalized, the value chains being connected, smart and decentralized (Hartmann \& Halecker, 2015).

For Gobble (2014) the IIoT, is more comprehensive than cloud computing, 3D printing and big data. The implementation of the IIoT is synonymous of continuous efforts in establishing cyber-physical connections that allow the interaction of the physical and virtual world. Thus, factory environments become more flexible, smarter and able to respond effectively to accelerated innovation cycles.

Regarding this new industrial perspective, Basl (2017) and Khan et al. (2017) stated that the trends advocated by the fourth industrial revolution provide the basis for Industry 4.0, which is based on the application of modern information and communication technology, which are connected and embedded in the field of industrial automation, data networking and manufacturing technologies, such as the use of 3D printing, smart production, human-machine interaction, remote operations, among others.

The implementation of Industry 4.0 in companies contributes to potential changes occurring, from new manufacturing procedures, changing a production system, that consists of a supply chain, into a smart production system based on the cyber physical interaction of connected components, thus allowing business and industrial processes and activities be integrated and make the manufacturing system more flexible, economical, and environment-friendly (Kagermann et al, 2013; Wang, Wan, Li, \&, Zhang 2016).

Kagermann et al. (2013) stated that these potentials made it possible: 
1) To meet individual customer requirements: Individual customer service is achievable due to the possibility of using customized criteria in the design, layout, ordering, planning, manufacturing and production steps. Therefore, batch production with low volumes will remain profitable, since the manufacturing process can be unique and will only take up the costs related to the customer's wishes and expectations.

2) Flexibility: A system built on Cyber Physical Systems (CPS) can reconfigure itself dynamically in several dimensions, such as quality, time, risk, robustness, price and suitability according to the given parameters of the environment. CPS systems are integrations of computing and physical processes. Lee (2008), corroborates by stating that embedded computers and networks monitor and control the physical processes, usually with feedback loops, where the physical processes affect the calculation and vice versa.

3) Optimized decision process: The implementation of CPS systems allows a global view of processes in real time, managing impacts on project decisions, procedures and agility in responses to any potential failures.

4) Productivity and resource efficiency: The strategic objectives of manufacturing apply to the production capacity with minimum available resources, for a given level of production. Thus, impacts regarding energy usage and pollutant emissions are reduced.

5) Creation of new value opportunities through new services: The large volume of data generated by smart equipment and sensors, create opportunities for new jobs, services, and enable accessibility for small businesses and startups in this new economic context.

6) Response to demographic change in the workplace: Joint efforts between organization and employees, which enable human beings and technologies to interact, will help companies develop new ways of working, that are more flexible and that create competitive advantage. Thus, it will be possible to enable people keep working and producing for longer.

7) Work-life balance: In companies that use CPS, the needs of their employees between work-life balance and professional development can be met, since intelligent systems can assist in more flexible work activities, thus helping to meet personal and business requirements.

Thus, in this new context, it is possible to state that the processes used in Industry 4.0 are based on the productive interdependence in the global industry, diversifying the origin of the value added to the general flow of goods and services (Gereffi, 2013).

\subsection{Metrics for Evaluating Scientific Productions}

The process that begins with research must take into consideration a qualitative and quantitative evaluation, always aiming to identify productive sources and their contributions to academia, public and private institutions. In this regard, understanding how metrics are used to evaluate scientific production is of major importance for the researcher and for the development of a research. This article presents scientific indicators such as the Thomson Reuters Corporation Impact Factor (IF), the H-index proposed by Hirsch (2005) and SCImago Journal Rank (SJR), which is part of the Scopus database. Finally, the concepts of Bibliometrics are presented.

\subsubsection{Impact Factor (IF)}

Along with the number of citations, the science of Bibliometrics uses metrics formed from indexes to evaluate a scientific paper. Among the metrics used are the Impact Factor (IF), the H-index and the SJR.

Eugene Garfield, founder of the Institute for Scientific Information (ISI) which is now part of the Thomson Reuters Corporation, created the IF (Impact Factor) in 1955. Since 1972, IFs are annually calculated for ISI-indexed journals and then, published, by Thomson Reuters in the Journal of Citation Reports (JCR) (Garfield, 2006). 
Among the various approaches to evaluating the quality of a journal proposed by researchers, the one that stands out the most is the evaluation of the quality of citations that are received in journals (Kodrzycki, 2006). An analysis of the networks of scientific articles from sophisticated mathematical algorithms can be used to estimate the quality of citations (Price, 1965).

Nowadays, it is common for researchers to consider the value of the IF to choose a journal that allows greater visibility in the writing of their work. For librarians, the IF is a parameter for selecting the titles of greatest scientific interest that should compose the collection of a library. Moreover, publishers seek information and follow up the IF of the journals that have great importance for the academia and are sources of financial fundraising by the amounts charged for obtaining a specific title. Funding agencies, which are responsible for scientific policies, use the IF to select researchers and institutions that have greater merit and will better fulfill the demands of the institutions (Thomaz, Assad, \& Moreira, 2011).

The IF represents the measure of the average number of citations of a scientific article published in a particular journal and field of knowledge. Therefore, the higher is the number on citations of a publication, the greater will be its importance for academia and researchers (Garfield, 2006).

Ruiz, Greco and Braile (2009) support the use of the IF indicator and claim that, if on the one hand the opinions of authors are unfavorable to the use of the IF, on the other hand, there is nothing better. Therefore, the index should be used as a good technical resource for evaluating scientific publications.

The IF is calculated by dividing the number of citations a journal receives for published articles in the two previous years to the year of calculation, by the number of articles published in this period. The IF formula is represented by:

Equation 1. Impact Factor Formula

$$
F I_{n}=\frac{\text { citações }_{n-2}+\text { citações }_{n-1}}{\operatorname{artigos}_{n-2}+\operatorname{artigos}_{n-1}}
$$

Source: adaptad from the Journal of Citation Reports (JCR) and Thomson Reuters (2020).

This way, if we take this formula into consideration, to calculate the IF of a certain magazine in 2011, we will have:

Equation 2. Impact Factor Formula

$$
F I_{2011}=\frac{\text { citações }_{2009}+\text { citações }_{2010}}{\text { artigos }_{2009}+\text { artigos }_{2010}}
$$

Source: adaptad from the Journal of Citation Reports (JCR) and Thomson Reuters (2020).

From the inserted data in the IF formula, it is possible to conclude that the impact factor is efficient in evaluating the quality of a journal, however, it is not useful when analyzing the scientific quality of a single article published by a researcher or an institution (Quindós, 2009).

Although the IF is considered an instrument to evaluate the quality of scientific journals, authors who have investigated the methodological aspects used to calculate this index have presented some criticism. 
The validity of the IF includes self-citation, which is possible to manipulate and misuse. Some journals that exclusively publish review articles or original articles have a higher IF than journals that are dedicated to publishing only original articles. Letters to the publisher or editorials do not count in the denominator of the calculation, but they can be cited and are considered in the numerator of the IF calculation. Thus, journals that publish large numbers of articles, which are not, in total, scientific, may have the IF inflated by this calculation bias (Garfield, 2000; Falagas, Pitsouni, Malietzis, \& Pappas, 2008; Antunes, 2015).

The different areas or even sub-areas of knowledge, also influence the calculation of the impact factor, since the number of references cited per article may be different. Articles in the area of exact sciences, which have lower citation density, will have a lower impact factor than articles in the health area. Experience in surveying articles published in the health area shows that they have a higher IF than articles published in the exact area (Garfield, 2000).

Antunes (2015) adds that the number of journals per area of knowledge, the variation in the number of references per article in each area, or the regionalism of some areas and journals, should be discussed and analyzed when using the IF index for the choice of scientific productions that will be part of the knowledge construction process.

The lack of evaluation of the quality of citations is a negative factor to the use of this indicator for decision making regarding the use of a scientific work by a researcher who wants to deepen in a theme or area of research (Delavalle et al., 2007). Another factor criticized by authors is the intensive use of the English language in publications, which limits the analysis of other scientific papers that do not use that language in the development of a research (Winkmann, Schlutius, \& Schweim, 2002).

Panés and Gisbert (2009) state that taking the IF indicator as a basis for analyzing a scientific article, and predicting the quality and relevance of a researcher, is not a good decision. In analysis, the authors state that the IF should be complemented with other indicators that demonstrate the quality of a scientific research.

\subsubsection{H-index}

Another indicator used to evaluate scientific production is the H-index. Physicist Jorge Hirsch in 2005 proposed it, and it aims to simultaneously measure the productivity of an academic work and its impact, taking into account the most cited articles by the author. This index allows us to know the largest number " $h$ " of scientific articles of a researcher, which have at least the same number " $h "$ of citations each (Costas, \& Bordons, 2007).

The $\mathrm{H}$ index refers to the highest number " $h$ " of a researcher's published scientific articles who has at least the same number "h" of citations each. For example, a researcher with an h-index of 30 is one who had published at least 30 scientific articles, each of which has been cited by others at least 30 times (Thomaz, Assad, \& Moreira, 2011). The ponderation excludes poorly cited papers and disregards highly cited articles if they are isolated examples (Antunes, 2015).

The h-index is a good indicator for presenting the balance between the number of publications and citations of an author. The advantage of using the h-index is the combination of a measure that reflects the quantity and impact of production, as well as the quality of the researcher (Thomaz, Assad, \& Moreira, 2011).

The h-index measures the trajectory of an author, his or her biography and, from this point of view, what is important is not only the h-values but also the differences in h-values between authors. Therefore, one should always take into consideration the h-index with the impact index for the analysis of a scientific production (Panés, \& Gisbert, 2009).

The applicability of this index is also used to measure the productivity and impact of research groups, universities, and scientific journals (Antunes, 2015).

It can be calculated from the ISI/ Thompson Scientific Reuters Web of Science database. To use this functionality, you must input the author's "citation name" in the appropriate space of the search platform and wait for the articles and their 
citations to be generated. In the case of a homonymous author, you must exclude the articles that are not authored by the author/researcher in question. After this procedure, the "Create Citation Report" function should be activated to generate the Hindex, the total number of citations and the average number of citations per paper (ISI, ).

Antunes (2015) lists the advantages and disadvantages of using the H-index to analyze scientific productions. As advantages, the author states that: 1) the use of the h-index is easily accessible through the Web of Science database, the composition of the formula used for calculation and its result is easy to understand; 2) the use of the h-index contributes to characterize objectively the scientific production of a researcher, especially in the fields that already have a culture of publications in indexed journals, thus facilitating decision making about eventual promotions, award attribution and allocation of funding; 3) the composition of the h-index allows combining a measure of quantity and impact of a research in a single indicator and; 4) due to its calculation composition, it presents a better performance when compared to other indicators, such as IF, number of paperss, number of citations, number of highly cited papers and citations per paper, which are used to evaluate the scientific productivity of the researcher (Antunes, 2015).

As disadvantages, Antunes (2015) states that: 1) because of the fact that the volume of citations varies among researcher communities, the h-index cannot be used to compare researchers in different fields; 2) the use of self-citations can manipulate the use of the h-index; 3) when used in books, the importance of the paper is the same and this decision makes it difficult to compare researchers inserted in fields where there is a culture of publishing research results in books, as an example, the humanities area; 4) in articles with several authors, it is impossible to evaluate the individual participation of each one and; 5) the impact of a publication should be analyzed from other aspects such as its contribution to technological innovations, the formulation of public policies and factors related to the management and competitiveness of public and private institutions.

\subsubsection{Scimago Journal Rank (SJR)}

The SJR indicator is an open access resource formed by the Scopus database, which lists a varying set of journal titles from various countries and languages (Falagas, Pitsouni, Malietzis, \& Pappas, 2008).

The publication of articles in several languages becomes a differential of the SJR indicator, because in the calculation of the IF indicator, which uses the Web of Science database, only articles published in the English language are considered (Mueller, 2006).

Both indicators use the division of a journal's citations by journal articles over a three-year period (Falagas, Pitsouni, Malietzis, \& Pappas, 2008). However, differently from the IF, the SJR indicator assigns different weightings to citations, taking into account the prestige of a citing journal without the influence of the journal that showed self-citations (Bollen, Rodriquez, \& Van De Sompel, 2006).

By applying the PageRank algorithm in the Scopus database, the SJR indicator aims to express the average number of pondered citations received in a given year and documents published in the journal in the previous three years. This calculation basis contributes to the prevention of excessive use of self-citations of the journal, considering a maximum of $33 \%$ of total citations (González-Pereira, Guerrero-Bote, \& Moya-Anegón, 2010).

Falagas, Pitsouni, Malietzis and Pappas (2008) researched the main characteristics and qualities of the journals that use the IF and SJR indicators. To do so, the authors searched for information on the official websites that hold the database used to calculate each index: ISI-Web of Science for the IF indicator and Scopus for the SJR indicator. They listed the top 100 journals with IF and their rankings in the SJR indicator list.

In analysis, the authors concluded that the main differences between the IF and SJR indicators, are in the databases used as the source for citations, in the methodologies used to estimate the indexes, in the importance assigned to citations, in 
the usage of self-citations, in the timeframe analyzed and in the type and quantity of articles a journal considers in the calculation denominator for each index. For the authors, the SJR database is open, and that makes it easy to access by all researchers. As for the content presented in each database, the authors concluded that the Scopus database includes a higher number of journals, from several countries and publications in several languages.

The Web of Science database includes English language articles and takes into consideration in the calculation of the indicator, citations originated from a subset of publications in the English language. This factor excludes articles published in other languages and consequently influences the evaluation of the category of journals. However, the authors state that although the database includes a larger number of journals in other languages, English still overlaps and constitutes $15 \%$ of the total number of journals included in the survey. A limitation found in the use of the Scopus database is its temporal limitation. Only after 1996, there is available data regarding the citations (Falagas, Pitsouni, Malietzis, \& Pappas, 2008).

Regarding the methodology used in the calculation of the indexes, it is observed that the calculation of the SJR indicator takes into consideration not only an absolute number, but also the quality of citations received by a journal. In the IF calculation, only the citations received are considered in a quantitative way. However, it is important to note that articles published in journals have greater impact if they are cited in journals of high scientific quality. Thus, the IF indicator, although it has reservations presented by authors, is still a source of reference for researchers to use it in scientific citations (Falagas, Pitsouni, Malietzis, \& Pappas, 2008).

In view of the above, regarding the metrics for analyzing a scientific article, it is possible to conclude that the scientific merit of a paper should be based on an association of measures to be used by the researcher. The bibliometric analysis is important, as are the IF, h-index and SJR indicators. However, it is important to take into consideration a set of indicators in order for the evaluation and merit of a researcher to be sufficient and fair (Antunes, 2015).

\subsubsection{Bibliometrics}

The science that is dedicated to the quantitative and statistical technique of scientific productions and contributes to the measurement of production indexes, as well as the dissemination of this knowledge, is called Bibliometrics (Okubo, 1997; Araújo, 2006).

For Goffman (1966), Bibliometrics allows one to estimate the levels of importance of papers in several lines of research and areas of knowledge, as well as to evaluate the behavior of these lines of research. The bibliometric analysis is based on the number of citations of a scientific article and is the most used source to recognize the quality and importance of scientific productions (Araújo, 2006).

The knowledge of bibliometric indexes is of major importance for researchers who need to obtain information and inputs for their research, since the published works are evaluated using bibliometric tools (Toro \& Amezcua, 2006).

On the other hand, for Panés (2009), bibliometric indexes have limitations and must be considered after a peer joint review in order to have a more accurate and legitimate analysis of a scientific paper. Only the use of the number of citations to evaluate a scientific paper has limitations.

\section{Methodology}

The present research is defined as an exploratory study, with the purpose of expanding knowledge on the subject "Industry 4.0" and contributing to future research by investigating the academic production.

Based on Zupic, and Cater (2015) they used bibliometric methods that are suitable to map a field of knowledge in a different perspective considering the study research is adequate with what is being evaluated. 
This is a bibliometric analysis with the purpose of investigating in the Web Of Science database, the papers produced in the areas of Management, Business and Economics, on the topic "Industry 4.0" in the period from 2011 to 2020.

The choice of starting the time period in 2011 is related to the time when the term "Industry 4.0" was first used in Germany.

The choice for the areas management, business and economics is due to the theme's relationship with new business and management models. On the other hand, the choice is enhanced by the theme's contribution to the economy of a country, region, or activity sector. In this same line of research, Li (2013) states that the publications on strategic management and operational management have long presented a series of indicators that allow the analysis of a nation's manufacturing capacity. Among these indicators are: low-cost production, differentiation strategies, such as the development of new products and technologies, innovations, and workforce development. Note that all the indicators mentioned are related to the three research environments chosen in this paper: Management, Business and Economics.

From on the bibliography survey, the published articles were analyzed by the metrics of number of citations, Impact Factor, and the journals that published the scientific articles on the researched theme.

The research protocol involved seven stages. In the first stage articles on the topic "Industry 4.0" were extracted from the Web of Science platform database, by filtering the areas of Management, Business and Economics.

The first gathering of data on the topic topic of "Industry 4.0" resulted in 2,253 papers published in the Web of Science database in the period from 2011 to 2020.

In the following stage, the activities of selection and exclusion of publications that met the criteria determined for the search on the topic "Industry 4.0" were performed, as shown in Table 1.

Table 1. Research Protocol for the systematic review of published articles.

\begin{tabular}{|ll|}
\hline \multicolumn{1}{|c|}{ Search Criteria } & \multicolumn{1}{c|}{ Industry 4.0 } \\
\hline Database & Web of Science \\
Researched areas & Business, Management and Economics \\
Exclusion Criteria & Non-Business, Management and Economics documents \\
Language & English \\
Types of documents & Papers \\
Period of publication & 2011 a 2020 \\
\hline
\end{tabular}

Source: Elaborated by the authors (2021).

Using the method of inclusion and exclusion there remained 173 articles published in 50 journals in the areas of business, management and economics. In the total universe of 173 articles, it was observed that some journals did not present the impact factor. This evidence leads to the inference that, although a high number of articles have been published in journals with impact factor, this indicator - impact factor - is not the only one to be taken into consideration for the decision making of scientific relevance. Other analyses should also be considered, such as the importance of the article's content and the relevance of the subject to the research to be carried out. This fact also aroused interest in checking other metrics for a more robust analysis.

In the third stage, a bibliometric analysis of the indexed and categorized publications was performed. In the subsequent stage, information was imported into a computerized database, using Excel software, with variables related to the year of publication, authors' names, number of citations and journals' names. In the fifth stage, we collected data related to the impact factor of each journal from the Scopus database or from the journals' websites. In the sixth stage, data was imported into the Statistical Package Social Science software (SPSS 22.0) in order to apply Spearman's correlation analysis technique between the number of citations and the impact factor of the journals. The application of this technique aimed to evaluate the 
convergence between the impact indicators of journals that dealt with the theme "Industry 4.0". In the last stage, the cluster analysis technique was applied using the Statistical Package Social Science software (SPSS 22.0). The purpose of applying this technique is to group the indexing journals of the selected articles, according to the structure of the data by the indicators of Impact Factor, number of citations, H-index and Scimago Journal Rank (SJR).

The intention of this more careful analysis regarding the publications in journals was to consider other indicators besides the Impact Factor in which the journals are classified.

Hair et al. (2009) stated that the clustering technique aims to classify objects so that each object is similar to the others in the grouping, based on a set of chosen characteristics. Thus, to perform the cluster analysis they checked the assumptions for the use of the technique. The first premise has to do with sample size. The second premise emphasizes that if atypical observations are detected, they should be eliminated.

In this sense, we first performed the normality test by the histogram of the indicators Impact Factor, SJR, H-index and Total citations in the last three years. The existence of outliers was detected, so the standardization by $\mathrm{Z}$ scores was performed. The clustering technique selected in this paper was the Hierarchical Method, because it is the most appropriate for small samples.

\section{Results and Discussion}

\subsection{Descriptive Analysis of Data}

This subsection presents the descriptive analysis of the data with the number of articles published per year, the journals that have published on Industry 4.0 and the convergence analysis of the Impact Factor and number of citations indicators. This convergence analysis demonstrates the correlation between the "rankings" of the Impact Factor and number of citations variables.

In the first descriptive step, the year of publication of the selected articles was analyzed in order to verify the chronological evolution of publications over the period 2011 to 2020. Figure 1 shows the total number of articles published by year. It is noted that the first two articles published on the topic "Industry 4.0" in the areas of Management, Business and Economics are dated 2016, and there was a significant increasing of publications from 2018.

Figure 1. Number of published Industry 4.0 articles per year.

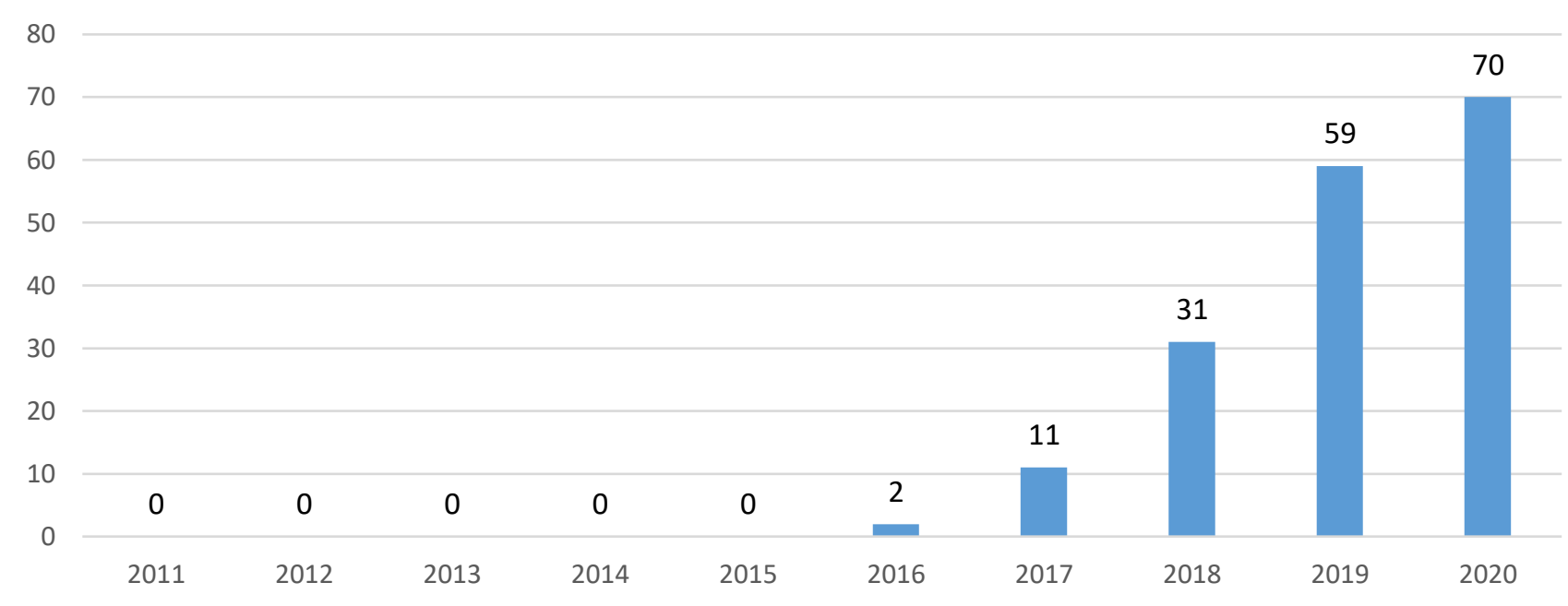

Source: Data extracted from Web of Science (2020). 
Table 2 shows the percentage of articles published from 2011 to 2020.

Table 2. Number of publications on Industry 4.0 by year.

\begin{tabular}{l|l|l}
\hline \multicolumn{1}{c|}{ Year } & \multicolumn{1}{c}{ Frequency } & \multicolumn{1}{c}{ Percentage } \\
\hline 2011 & 0 & 0 \\
\hline 2012 & 0 & 0 \\
\hline 2013 & 0 & 0 \\
\hline 2014 & 0 & 0 \\
\hline 2015 & 0 & 0 \\
\hline 2016 & 2 & 1,16 \\
\hline 2017 & 11 & 6,36 \\
\hline 2018 & 31 & 17,92 \\
\hline 2020 & 59 & 34,10 \\
\hline Total & 70 & 40,46 \\
\hline
\end{tabular}

Source: Elaborated by the authors (2021).

It can be seen from the data in Table 2 that the percentage of publications on the topic "Industry 4.0 ", in the areas of business, management and economics, has evolved significantly in the period from 2011 to 2020.

In the period from 2011 to 2015 there were no published articles. In the years 2016 and 2017, the percentages found were 1.266 .00 and $6.36 \%$, respectively. From 2018, publications increased, representing $17.92 \%$ of publications, and from 2019, a significant increase in publications occurred, with $34.10 \%$ of articles being published. In 2020, this number continues to increase and represents $40.46 \%$ of the total articles published.

Regarding the journals that have published articles on Industry 4.0, Table 3 shows this reality.

Table 3. Number of publications on Industry 4.0 from 2011 to 2020.

\begin{tabular}{|c|c|}
\hline Journal & Indexed Papers \\
\hline Journals Of Manufacturing Technology Management e Systems Research and Behavioral & 14 \\
\hline Journal Technological Forecasting and Social Change & 10 \\
\hline Entrepreneurship And Sustainability Issues e Logforum & 6 \\
\hline Competitiveness Review, Journal Of Intellectual Capital & 5 \\
\hline Polish Journal Of Management Studies & 5 \\
\hline Sosyoekonomi & 5 \\
\hline Total Quality Management \& Business Excellence & 5 \\
\hline Problemy Zarzadzania-Management Issues & 4 \\
\hline Administrative Sciences & 3 \\
\hline Independent Journal Of Management \& Production & 3 \\
\hline International Journal Of Productivity And Performance Management & 3 \\
\hline Business Process Management Journal, & 2 \\
\hline Direccion Y Organizacion, Economic Annals-XXI & 2 \\
\hline Economics Of Innovation And New Technology & 2 \\
\hline Foresight And Sti Governance & 2 \\
\hline International Journal Of Organizational Leadership & 2 \\
\hline Journal Of World Business & 2 \\
\hline Management Decision & 2 \\
\hline Technology Analysis \& Strategic Management & 2 \\
\hline Technology Innovation Management Review & 2 \\
\hline Transformations In Business \& Economics & 2 \\
\hline Other journals & 90 \\
\hline Total & 173 \\
\hline
\end{tabular}


Source: Elaborated by the authors (2021).

From the collected indicators, a correlation analysis was performed in order to verify the convergence between the metrics in number of citations and the impact factor of the journals that published articles with the theme Industry 4.0, as shown in Table 4.

Table 4. Spearman Correlation Analysis.

\begin{tabular}{lll}
\hline Indicator & $\mathbf{1}$ & $\mathbf{2}$ \\
\hline 1 Total of citations & 1 & $0,299 * *$ \\
2 Impact Factor & $0,299 * *$ & 1 \\
\hline
\end{tabular}

The correlation is significant at the level: $* * p<0,01$ Source: Elaborated by the authors (2021).

The results revealed that the various measurements of the Impact Factor and number of citations indicators converge with each other. This convergence between the number of citations and the impact factor indicated that the two measurements can be used to verify the scientific importance of publications. It is emphasized that these quantitative revelations contribute to a decision-making process, but they have limitations in the content analysis.

It is considered very important to note that the quantitative analysis of the indicators paves the way for research, but it is not enough for the final decision making. From the application of this technique, it was possible to further the investigation with cluster analysis, in order to classify the journals, based on their Impact Factor, number of citations, H-index and Scimago Journal Rank (SJR) indicators.

\subsection{Clustering Analysis}

In this subsection the results of the cluster analysis are presented (Hair et al., 2009). From the cluster analysis the authors verified the clusters resulting from journals with high internal homogeneity (within the clusters) and high external heterogeneity (between clusters) (Hair et al., 2009, p. 430). Considering the article with the highest number of citations and the cluster in which it is part, it is possible to analyze the scope of the journal as well as the research carried out by the authors.

For a better identification and analysis of the clustering data, the authors chose to divide this analysis into three stages: in the first stage, they present the description of each journal with its publication and indicators. In the second stage, they chose to analyze the articles randomly, that is, due to the scope of this work, and meeting the outlined objectives, they analyzed the most cited article and the least cited article, followed by their Impact Factor.

This decision made by the authors aims to help future researchers in the survey of productions that deal with the theme in question. In the third stage, the data found in each cluster will be discussed with regard to the journals and articles selected for analysis. 
Table 5. Cluster analysis of publications on Industry 4.0.

\begin{tabular}{|c|c|c|c|c|c|}
\hline Journal & $\underset{\mathbf{r}}{\text { Cluste }}$ & Title of the Article & year & $\begin{array}{l}\text { No. } \\
\text { Citations }\end{array}$ & $\begin{array}{l}\text { Impact } \\
\text { Factor }\end{array}$ \\
\hline $\begin{array}{l}\text { Technological Forecasting and } \\
\text { Social Change }\end{array}$ & 1 & $\begin{array}{l}\text { China's manufacturing locus in 2025: With a comparison of Made-in-China } 2025 \\
\text { and Industry } 4.0\end{array}$ & 2018 & 133 & 5,846 \\
\hline $\begin{array}{l}\text { Entrepreneurship and Sustainability } \\
\text { Issues }\end{array}$ & 2 & $\begin{array}{l}\text { Design management as a domain of smart and sustainable enterprise: business } \\
\text { modelling for innovation and smart growth in industry } 4.0\end{array}$ & 2016 & 19 & 5,470 \\
\hline $\begin{array}{l}\text { Journal of Manufacturing } \\
\text { Technology Management }\end{array}$ & 2 & The future of manufacturing industry: a strategic roadmap toward Industry 4.0 & 2018 & 88 & 1,173 \\
\hline $\begin{array}{l}\text { Journal of Enterprise Information } \\
\text { Management }\end{array}$ & 2 & $\begin{array}{l}\text { Mobile supply chain management in the Industry } 4.0 \text { era An annotated bibliography } \\
\text { and guide for future research }\end{array}$ & 2018 & 19 & 3,230 \\
\hline Management Decision & 2 & Identifying Industry 4.0 IoT enablers by integrated PCA-ISM-DEMATEL approach & 2019 & 12 & 1,320 \\
\hline $\begin{array}{l}\text { Business Process Management } \\
\text { Journal }\end{array}$ & 2 & $\begin{array}{l}\text { Towards Industry } 4.0 \text { Mapping digital technologies for supply chain management- } \\
\text { marketing integration }\end{array}$ & 2019 & 38 & 1,460 \\
\hline Futures & 2 & $\begin{array}{l}\text { Foresight and technology assessment for the Austrian parliament - Finding new } \\
\text { ways of debating the future of industry } 4.0\end{array}$ & 2019 & 6 & 2,214 \\
\hline $\begin{array}{l}\text { Electronic Commerce Research and } \\
\text { Applications }\end{array}$ & 2 & $\begin{array}{l}\text { A } 2020 \text { perspective on A dynamic model for the evolution of the next generation } \\
\text { Internet - Implications for network policies: Towards a balanced perspective on the } \\
\text { Internet's role in the } 5 \mathrm{G} \text { and Industry } 4.0 \text { era }\end{array}$ & 2020 & 1 & 3,824 \\
\hline $\begin{array}{l}\text { IEEE Transactions on Engineering } \\
\text { Management }\end{array}$ & 2 & An Interpretive Structural Analysis for Industry 4.0 Adoption Challenges & 2020 & 0 & 2,05 \\
\hline $\begin{array}{l}\text { International Journal of } \\
\text { Productivity and Performance } \\
\text { Management }\end{array}$ & 2 & $\begin{array}{l}\text { Performance measurement for supply chains in the Industry } 4.0 \text { era: a balanced } \\
\text { scorecard approach }\end{array}$ & 2020 & 1 & 2,65 \\
\hline Journal of Intellectual Capital & 2 & $\begin{array}{l}\text { Human capital and AI in industry 4.0. Convergence and divergence in social } \\
\text { entrepreneurship in Russia }\end{array}$ & 2020 & 9 & 1,184 \\
\hline $\begin{array}{l}\text { International Journal of Innovation } \\
\text { Management }\end{array}$ & 3 & Sustainable industrial value creation: benefits and challenges of industry 4.0 & 2017 & 62 & 1,3 \\
\hline Multinational Business Review & 3 & Industry 4.0, global value chains and international business & 2017 & 61 & 1,97 \\
\hline $\begin{array}{l}\text { Journal of Modelling in } \\
\text { Management }\end{array}$ & 3 & $\begin{array}{l}\text { Development of an Industry } 4.0 \text { maturity model for the delivery process in supply } \\
\text { chains }\end{array}$ & 2018 & 6 & 1,860 \\
\hline $\begin{array}{l}\text { Technological and Economic } \\
\text { Development of Economy }\end{array}$ & 3 & Management approaches for industry 4.0-the organizational culture perspective & 2018 & 10 & 1,7 \\
\hline $\begin{array}{l}\text { European Journal of Innovation } \\
\text { Management }\end{array}$ & 3 & Organizational and managerial challenges in the path toward Industry 4.0 & 2019 & 12 & 1,980 \\
\hline
\end{tabular}


Research, Society and Development, v. 10, n. 11, e193101118923, 2021

(CC BY 4.0) | ISSN 2525-3409 | DOI: http://dx.doi.org/10.33448/rsd-v10i11.18923

\begin{tabular}{|c|c|c|c|c|c|}
\hline $\begin{array}{l}\text { International Journal of Technology } \\
\text { Management }\end{array}$ & 3 & $\begin{array}{l}\text { Management of Industry 4.0-reviewing intrinsic and extrinsic adoption drivers and } \\
\text { barriers }\end{array}$ & 2019 & 0 & 1,592 \\
\hline $\begin{array}{l}\text { Journal of Management } \\
\text { Development }\end{array}$ & 3 & The new talent management challenges of Industry 4.0 & 2019 & 4 & 1,690 \\
\hline Measuring Business Excellence & 3 & Dynamic capabilities in Italian leading SMEs adopting industry 4.0 & 2019 & 1 & 1,210 \\
\hline Competitiveness Review & 3 & $\begin{array}{l}\text { Digital transformation priorities of India's discrete manufacturing SMEs - a } \\
\text { conceptual study in perspective of Industry } 4.0\end{array}$ & 2020 & 1 & 2,470 \\
\hline $\begin{array}{l}\text { Economics of Innovation and New } \\
\text { Technology }\end{array}$ & 3 & $\begin{array}{l}\text { What drives the capacity to integrate Industry } 4.0 \text { technologies? Evidence from } \\
\text { European R\&D projects }\end{array}$ & 2020 & 5 & 1,563 \\
\hline $\begin{array}{l}\text { Journal of Fashion Marketing and } \\
\text { Management }\end{array}$ & 3 & Managerial and Industry 4.0 solutions for fashion supply chains & 2020 & 0 & 1,97 \\
\hline $\begin{array}{l}\text { Journal of Multi-Criteria Decision } \\
\text { Analysis }\end{array}$ & 3 & $\begin{array}{l}\text { A two-stage fuzzy approach for Industry } 4.0 \text { project portfolio selection within } \\
\text { criteria and project interdependencies context }\end{array}$ & 2020 & 1 & 0,670 \\
\hline $\begin{array}{l}\text { Knowledge Management Research } \\
\text { \& Practice }\end{array}$ & 3 & A conceptual model of knowledge dynamics in the industry 4.0 smart grid scenario & 2020 & 2 & 1,583 \\
\hline Local Economy & 3 & Integrating Industry 4.0 plans into regional innovation strategies & 2020 & 0 & 1,360 \\
\hline $\begin{array}{l}\text { Systems Research and Behavioral } \\
\text { Science }\end{array}$ & 3 & Industry 4.0 in systems thinking: From a narrow to a broad spectrum & 2020 & 1 & 1,034 \\
\hline Economic Annals-XXI & 4 & Society. Personality. Technologies: Social Paradoxes of Industry 4.0 & 2017 & 6 & 0,550 \\
\hline Foresight and STI Governance & 4 & Industry 4.0: New Challenges and Opportunities for the Labour Market & 2017 & 24 & 0,359 \\
\hline Organizacija & 4 & Industry 4.0 and the New Simulation Modelling Paradigm & 2017 & 28 & 0,870 \\
\hline Business and Economic Horizons & 4 & $\begin{array}{l}\text { Changes in industrial structure of GDP and stock indices also with regard to the } \\
\text { Industry } 4.0\end{array}$ & 2018 & 4 & Sem fator \\
\hline Economies & 4 & Effects of Industry 4.0 on the Labor Markets of Iran and Japan & 2018 & 3 & Sem fator \\
\hline Ekonomista & 4 & Industry 4.0 and international economic cooperation & 2018 & 0 & 0,080 \\
\hline Foundations of Management & 4 & $\begin{array}{l}\text { The predictive maintenance concept in the maintenance department of the industry } \\
4.0 \text { production enterprise }\end{array}$ & 2018 & 0 & 0,656 \\
\hline $\begin{array}{l}\text { Polish Journal of Management } \\
\text { Studies }\end{array}$ & 4 & Industry 4.0 - are we ready? & 2018 & 44 & 0,400 \\
\hline Direccion y Organizacion & 4 & Industry 4.0, the new engine of industrial innovation & 2019 & 1 & 0,250 \\
\hline Intangible Capital & 4 & $\begin{array}{l}\text { The role of high-performance people management practices in Industry 4.0: The } \\
\text { case of medium-sized Spanish firms }\end{array}$ & 2019 & 0 & 0,790 \\
\hline $\begin{array}{l}\text { International Journal of } \\
\text { Computational Economics and } \\
\text { Econometrics }\end{array}$ & 4 & Technology diffusion of Industry 4.0: an agent-based approach & 2019 & 0 & 0,410 \\
\hline
\end{tabular}




\begin{tabular}{|c|c|c|c|c|c|}
\hline Journal of Corporate Real Estate & 4 & $\begin{array}{l}\text { A robust expert decision support system for making real estate location decisions, a } \\
\text { case of investor-developer-user organization in industry } 4.0 \text { era }\end{array}$ & 2019 & 0 & 1,050 \\
\hline Journal of Korea Trade & 4 & $\begin{array}{l}\text { Trade Facilitation for the Products of the Industry 4.0: The case of Customs } \\
\text { Classification of Drone }\end{array}$ & 2019 & 0 & 0,143 \\
\hline $\begin{array}{l}\text { Asian Journal of Technology } \\
\text { Innovation }\end{array}$ & 4 & $\begin{array}{l}\text { Frugal innovation and leapfrogging innovation approach to the Industry } 4.0 \\
\text { challenge for a developing country }\end{array}$ & 2020 & 0 & 0,336 \\
\hline $\begin{array}{l}\text { Economic Research-Ekonomska } \\
\text { Istrazivanja }\end{array}$ & 4 & $\begin{array}{l}\text { Evaluating strategies for implementing industry 4.0: a hybrid expert oriented } \\
\text { approach of BWM and interval valued intuitionistic fuzzy TODIM }\end{array}$ & 2020 & 0 & 1,380 \\
\hline $\begin{array}{l}\text { Environmental Economics and } \\
\text { Policy Studies }\end{array}$ & 4 & $\begin{array}{l}\text { Using ICT indicators to measure readiness of countries to implement Industry } 4.0 \\
\text { and the SDGs }\end{array}$ & 2020 & 1 & 0,560 \\
\hline $\begin{array}{l}\text { International Journal of Business } \\
\text { Performance Management }\end{array}$ & 4 & $\begin{array}{l}\text { Industry } 4.0 \text { and big data: role of government in the advancement of enterprises in } \\
\text { Italy and UAE }\end{array}$ & 2020 & 0 & Sem fator \\
\hline $\begin{array}{l}\text { International Journal of } \\
\text { Entrepreneurship and Innovation }\end{array}$ & 4 & $\begin{array}{l}\text { A conceptual model of entrepreneurial competencies needed to utilise technologies } \\
\text { of Industry } 4.0\end{array}$ & 2020 & 0 & Sem fator \\
\hline $\begin{array}{l}\text { International Journal of Shipping } \\
\text { and Transport Logistics }\end{array}$ & 4 & A value chain analysis of a seaport from the perspective of Industry 4.0 & 2020 & 0 & 0,914 \\
\hline $\begin{array}{l}\text { Journal of Advances in } \\
\text { Management Research }\end{array}$ & 4 & Industry 4.0 adoption key factors: an empirical study on manufacturing industry & 2020 & 0 & 1,000 \\
\hline Journal of Economic Policy Reform & 4 & $\begin{array}{l}\text { A global perspective on industry } 4.0 \text { and development: new gaps or opportunities to } \\
\text { leapfrog? }\end{array}$ & 2020 & 0 & 1,000 \\
\hline $\begin{array}{l}\text { SA Journal of Human Resource } \\
\text { Management }\end{array}$ & 4 & Industry 4.0: The role of human resource professionals & 2020 & 0 & Sem fator \\
\hline Journal of World Business & 5 & Backshoring strategy and the adoption of Industry 4.0: Evidence from Europe & 2019 & 16 & 5,194 \\
\hline \multicolumn{4}{|c|}{ Média de citações } & 12.63 & \\
\hline
\end{tabular}

Source: Elaborated by the authors (2021). 
It is observed from the data in Table 5, that the publication entitled "China's manufacturing locus in 2025: With a comparison of Made-in-China 2025 and Industry 4.0" from 2018, indexed in the Journal Technological Forecasting and Social Change, obtained the highest number of citations from the researched group. Moving forward in the investigation, the following subsection presents the results of the descriptive analysis of the publications, including the one with the highest number of citations.

\subsubsection{Descriptive analysis of the scope of the journals}

The Journal Technological Forecasting and Social Change, presented in the last Qualis evaluation an impact factor of 5.846 and aims to encourage publications that have in their scope methodologies and practices aimed at technological forecasting, as an example, the planning that involves the analysis of the interaction of technology with social, behavioral and environmental aspects.

The Journal of Manufacturing Technology Management presented in the last Qualis evaluation an impact factor of 1.173. It aims to give a broad international coverage of issues related to the management of manufacturing technology and the integration of production, design, supply and marketing functions of manufacturing companies. Emphasis is placed on the publication of articles, which seek to link theory to application or critically analyze real-life situations with the aim of identifying good manufacturing practices.

The International Journal of Innovation (IJIM) presented in the last Qualis evaluation an impact factor of 1.300.

It is the official journal of the International Society of Professional Innovation Management (ISPIM). Both IJIM and ISPIM take a multidisciplinary approach to addressing the many challenges of innovation management, rather than a narrow focus on a single aspect such as technology, R\&D, or new product development. Both are also international, inclusive and practical, and encourage active interaction between academics, managers and consultants.

O Polish Journal of Management Studies apresentou na última avaliação Qualis um fator de impacto de 0,400 e tem como objetivo publicar estudos teóricos e artigos empíricos de todas as áreas de gestão. Os temas abordados na revista são diversificados e dizem respeito a vários campos da gestão: contabilidade, teoria e gestão empresarial, marketing, gestão financeira, análise econômica, estatística, informática em gestão, logística, inovações e gestão de recursos humanos.

The Journal of World Business showed in the last Qualis evaluation an impact factor of 5.194 and aims to especially encourage submissions that break new ground or demonstrate new or counter-intuitive findings in relation to established theories or assumptions that embrace a variety of conceptual and theoretical traditions, including those drawn from the allied social and behavioral sciences. Submissions should develop new theory and/or test existing theory, and empirical articles may employ a variety of qualitative, quantitative, and other methodologies, as long as they are rigorous and appropriate. Although JWB's principal readers are academics and researchers, the journal values contributions that explore and explain the implications for global firms and their managers, as well as the consequences for public policies and the broader role of business in society.

\subsubsection{Descriptive analysis of Industry 4.0 publications}

\subsubsection{Descriptive analysis of Cluster 1 publication}

Only one article was grouped in cluster 1, which stood out among the 173 articles surveyed in the research, with 133 citations, by the date 11/11/2020 and was published in a Journal with the highest Impact Factor (5.846) among the journals. 
Li (2018) compared the Made In China 2025 plan with the German Industry 4.0 plan from variables classified into three categories: (i) manufacturing capacity with the indicators of GDP, industry value added as a percentage of GDP, hightech exports as a percentage of manufacturing exports "and" net foreign direct investment inflow; (ii) research and development with the indicators of R\&D expenditures and number of patent applications; and (iii) human capital with the indicators urban and rural residents, primary and secondary high school graduated, college graduated, post-graduate students, and returned to studying abroad.

In the research result $\mathrm{Li}$ (2018) stated that the guiding principles of the Made in China 2025 plan are to increase industrial capacity through innovation-driven manufacturing, optimize the structure of Chinese industry, emphasize quality over quantity, train and attract talent, and achieve green manufacturing through sustainable development. Both plans, Made In China 2025 and Industry 4.0, recognize the use of IoT in production, deployment of digital production network to create smart manufacturing systems, integrating the value chain and the creation of a social responsibility system that contributes to a global, innovative, and competitive manufacturing landscape.

\subsubsection{Descriptive analysis of Cluster 2 publications}

In Cluster 2, a higher number of clustered articles is observed, that is 10. It is inferred that in this cluster the occurrence of articles published in a journal with a higher impact factor, without citations, by the date 11/11/2020, such as the article entitled "An Interpretive Structural Analysis for Industry 4.0 Adoption Challenges", published in the journal IEEE Transactions on Engineering Management, with an impact factor of 2.05.

On the other hand, the article published by Gerlitz (2016), presented 19 citations and was published in a journal that presented an impact factor of 5.470. Gerlitz (2016) conducted a qualitative research of single case study type in a mediumsized company located in Berlin-Germany to investigate how design can be integrated into the strategic business orientation, accelerate the business model, and to what extent design integration and design value can be traced in small and medium-sized companies in the context of Industry 4.0.

The results pointed out that the company's performance was successful from the use of design which is considered a tool and process for innovation capacity within the premises of Industry 4.0 and the current paradigm of industrial development. However, the author draws attention to the statement that technological advancement, increased interconnectivity of machines and people, contribute to meeting customer needs, and enable a faster innovation process.

Morteza's (2018) article was cited 88 times, but its publication was in a journal with an Impact Factor of 1.173. Morteza (2018) sought, based on the state of the art, to contribute to the academia with the construction of a strategic roadmap for the transition to Industry 4.0. To this end, the author conducted a content analysis of 178 articles that aimed to research the phenomenon of Industry 4.0, from its design principles, technological trends and architecture.

The research result presented that Industry 4.0 is an integrative system of value creation, which in its composition presents 14 technological trends and 12 principles. As technological trends, Morteza (2018) found in the literature: Internet of Things - IoT, Internet of Services - IoS, Internet of Products - IoP, Internet of Data - IoD, Cloud Computing, Big Data, Blockchain, augmented reality (AR), Automation and industrial robotics, Cybersecurity, Additive manufacturing, Simulation and modeling techniques, CPS, and semantic technologies. As design principles, Morteza (2018) presented in his research: service and product manufacturing, smart factory, interoperability, Modularity, product customization, decentralization, virtualization, system integration, social responsibility, environmental sustainability, sustainable manufacturing and the implementation of lean, agile and green supply chain in the business model. As for the architecture of Industry 4.0, the author 
states that CPS, IoT-Internet of Things, IoS-Internet of Services, IoP-Internet of Products, and Blockchain technologies should be part of an Industry 4.0 architecture. Vertical and horizontal integration, and the merging of physical and virtual processes, are essential to succeed in an Industry 4.0 architecture. Finally, the author suggests a roadmap for the implementation of Industry 4.0, which follows the following steps: strategic planning for the transition to Industry 4.0, marketing strategies, human resources strategies, strategies to measure the maturity degree regarding the use of digital technologies, strategies for advanced manufacturing, and strategies for intelligent supply chain management.

Another consideration that must be taken into account in the cluster analysis is that the most current articles do not yet have a large number of citations, however, for its title and subject discussed, they can contribute to the development of a research. As an example, the article by Kim (2020), has one citation and was published in a journal with an IF of 3.824. Kim (2020), suggests building a dynamic model that enables the dual trajectory for 5G Internet and Industry 4.0 from network policies that enable greater Internet sophistication and contribute to the division of the network into 5G-enabled smart factories, artificial intelligence, and above all, meeting the needs of basic social connections. It is important to emphasize that the author calls attention to the emergence of new technologies that contribute to disruptive innovations and investments in network assets, which must keep up with the fast changes occurring in the virtual world. Otherwise, all investment in network assets will become obsolete and will not contribute to a fast and effective response of the services offered.

\subsubsection{Descriptive analysis of Cluster 3 publications}

In cluster 3, there were 15 articles clustered together. The prominent article in this cluster was published by Keil, Müller, Arnold, and Voigt (2017), featuring 62 citations and is published in a journal with an IF of 1.300, up to the date of $11 / 11 / 2020$.

Keil, Müller, Arnold, and Voigt (2017) researched how the Industrial Internet of Things - IIoT brings economic, ecological, and social benefits, and what are the challenges encountered by companies when deploying IIoT. To do so, they used the Triple Bottom Line-TBL concept, which aims to raise awareness of manufacturers to create sustainable value from an economic, social, and sustainable perspective (Elkington, 1998) and conducted a qualitative multiple case study type research with 46 manufacturing managers from three major German industries. In the result of the authors' survey, carried out with managers, it was stated that competitiveness is an opportunity/benefit that enables greater market penetration and participation, differentiation and competitive advantages. Financial benefits in terms of value creation, increase in sales volume and reduction in direct costs, operational costs, personnel costs, tools, R\&D and tangible investments involving the Engineering area, were pointed out as the second benefit of IIoT implementation. The increased effectiveness of equipment that contributes to a better product quality was also pointed out as an opportunity when investing in IIoT. The authors' research revealed that technical integration, organizational change, competitiveness with regards to manufacturers that need to adapt to change, and cooperation between companies, are factors that hinder IIoT deployment. The authors stated that the TBL model applied to IIoT, should be adjusted in three aspects: technical integration, data and information. Finally, the authors concluded that IIoT meets expectations regarding industrial value creation and meets sustainability requirements through a comprehensive assessment by manufacturers.

The article by Dutta, Kumar and Sindhwani (2020) was cited once, and is published in a journal with an IF of 2.470. The authors researched small and medium-sized companies in the manufacturing sector in India, with the objective of studying the functional areas that leverage digital technologies aimed at Industry 4.0. To do so, they conducted workshops with engineering managers in 250 SMEs to understand how mature these companies are for the transition to Industry 4.0. In 
analysis, the authors described that in the product design function, SMEs aim to do program management that will include customer requirements, development, and design specifications. In the manufacturing process definition function, SMEs intend to work with lists that feature the integration of manufacturing processes and define plans and processes integrated with product design. In the machine automation planning and simulation function, SMEs intend to simulate and validate manufacturing from planned processes to make decisions regarding automation, CNC and robotic programs. As for the production execution function, SMEs intend to leverage IoT, big data, and cloud technologies to gain operational insights and thus prioritize systems integration management. In the service function, which involves after-sales activities, SMEs intend to apply IoT technologies to integrate maintenance services to better serve customers.

From the research conducted, the authors related some gaps identified in the current world of SMEs in India which are: the lack of reporting, analysis, diagnostics and monitoring metrics due to most of the assets belonging to the companies not being ready for IoT. The operational part of the shop floor also showed gaps related to the equipment that is programmable, remains online and is used in the form of testing. While, if they were used based on the precepts of digital technologies, they could be programs to remain offline, thus contributing to a better use, speed, and accuracy of operations. The lack of alternatives for evaluation in the design function was also pointed out as a gap present in the researched SMEs. By simulating the design performance it is possible to perform several evaluations and select the ideal model.

The maturity assessment presented the two areas of greater aspiration that were divided into two categories: Metrics and Transformation. Metrics include areas of reporting and analysis, performance-based measurement, diagnostics, metrics, and knowledge management. Transformation areas encompass integrated quality management, device scheduling automation, scheduling, sequencing and line balancing, machine line cell automation, and simulation and alternative evaluation.

The actions identified in the research as priorities to be taken by Indian SMEs are related to connected machines, data capture and analytics which, within the precepts of Industry 4.0, mean the use of CPS, IoT, cloud computing and big data, which contribute to the elaboration of design, manufacturing and systems integration. Finally, the authors stated that from the research conducted in Indian SMEs, a roadmap should have the following sequence: "Integrate" in order to gain insights, "Digitize" to trigger the intervention of improvements in design and manufacturing, and, "optimize" from continuous improvements executed from metrics and in real time.

\subsubsection{Descriptive analysis of Cluster 4 publications}

Cluster 4 grouped 22 articles published in journals that have an IF equal to 1.0, less than 1.0, or have no Impact Factor. The most cited article presented in this cluster was the one written by Ślusarczyk (2018), with 44 citations and published in a journal with an IF of 0.400. The research of Ślusarczyk (2018) investigated the position of entrepreneurs regarding their involvement in the new Industry 4.0 scenario, indicating the degree of readiness for the implementation of digital technologies that are part of Industry 4.0, in order to present barriers encountered by companies for the transition to the new technological and organizational context.

he research was conducted based on secondary data, obtained from various reports and professional studies conducted by state institutions, consortia, and companies in the United States, Germany, Japan, Poland, and South Africa. The result of the research showed that there is great interest in presenting the challenges posed by Industry 4.0. Most reports present Industry 4.0 as a great opportunity for development and improvement of competitiveness; however, the strategies taken for the implementation of Industry 4.0 are different for countries, sectors of activity, or even for an individual company. Which according to the author may be related to the economy's degree of maturity, investment opportunities, and innovation culture. 
Based on the reports surveyed, the author sought to relate the opinions of entrepreneurs as to the meaning of Industry 4.0. In his analysis, he found that most entrepreneurs recognize the importance of Industry 4.0 and support the development and application of new technologies, they recognize that these movements may be threats or opportunities for their companies' business models. According to the survey, entrepreneurs from the United States, Germany, and Japan see Industry 4.0 as a market opportunity and not as a threat. Companies from Germany and from the United States indicate in their reports that they are able to face the challenges brought by Industry 4.0. In Japan, the same does not occur, which may be related to the perception and the necessary requirements for the implementation of Industry 4.0 in the country. Germany was the country that presented the highest level of implementation. In case of software integration, Poland stands out and is ahead of Germany. As for the challenges, the survey presented that, globally, they are related to the lack of factors such as: digital culture and training, manager involvement, economic benefits, and financial investments in digital technologies. The lack of qualified personnel was identified as a barrier in Germany and South Africa.

The article by Ancarani, Di Mauro, and Mascali's (2019) was cited 16 times. The authors analyzed whether competitive priorities driven by backshoring moves, which is the reallocation of value chain activities regardless of geographic location and the existing corporate governance structure where the parent company is based (Rajkumar, 2010) are related to the technological choices available within the Industry 4.0 framework by firms after relocating production in Europe. To conduct the research, the authors built a secondary database containing 495 backshoring initiatives that were carried out in Europeanbased companies. Among the secondary data collected by the authors it is highlighted: information from newspapers and magazines, the researched companies' websites, and reports from consulting companies. The result showed that $58 \%$ of the research universe refers to large backshoring companies. Only 37\% are companies repatriated from China. The countries considered as backshoring in the survey were: Italy, which represented (26\%) of the survey universe, United Kingdom (18\%), France (14\%), Germany (12\%), Scandinavian countries (11\%), Netherlands (4\%), Spain (4\%) and other European countries $(11 \%)$.

According to the authors, the backshoring initiatives are associated with the adoption of Industry 4.0, when related to quality linked to product innovation, and also to the reduction of non-conformity costs, that is, to the waste costs that involve the production of a given product. On the other hand, the reduction of direct costs and the production responsiveness (production volume), were not considered in the authors' analysis as determining factors for backshoring companies to adopt technologies aimed at the context of Industry 4.0 (Ancarani, Di Mauro, \& Mascali, 2019).

\section{Conclusion}

This work aims to understand how the international publications on the subject "Industry 4.0" are characterized, from their scientific indicators. In order to meet the proposed objective, the techniques of Bibliometric analysis, Spearman Correlation and Clustering were applied.

The main revelations pointed out that the theme "Industry 4.0" is recent in terms of publications by the Web of Science platform. This fact is reinforced by the first publication date in the areas of Management, Business and Economics, in 2016, although a significant increase in publications is evidenced, starting in 2018. Another evidence of the configuration of publications on "Industry 4.0" is the Journals Of Manufacturing Technology Management and Systems Research and Behavioral that indexed 14 articles on the topic.

The publication entitled "China's manufacturing locus in 2025: With a comparison of Made-in-China 2025 and Industry 4.0", authored by Li (2018), made a comparative analysis of the Made In China 2025 plan with the German Industry 
4.0 plan. This paper stood out in the clustering configurations, being part of Cluster 1, featuring 133 citations, indexed in a Journal with the highest Impact Factor 5.846, named "Technological Forecasting and Social Change". So far, the argument of Garfield (2006) that the greater the number of citations of a publication, the greater its importance for academia and researchers, was supported by the evidence found.

In Cluster 2, 10 articles were grouped. A pertinent observation is required, such as the occurrence of articles published in journals with high impact factor, but without citations. Another evidence was that in cluster 3, 15 scientific publications were grouped together. The prominent article in this cluster was published by Keil, Müller, Arnold, and Voigt (2017), presenting 62 citations, indexed in a journal with an IF of 1.300. Cluster 4 grouped 22 publications in journals that have an IF equal to 1.0, less than 1.0 or having no Impact Factor. The most cited article presented in this cluster was that of Ślusarczyk (2018), with 44 citations and published in a journal with an IF of 0.400.

The results pointed to an inference path that, although the indicators, such as the Impact Factor, the H-index associated with the SJR metric, demonstrate a quantitative academic importance, the average number of citations of a scientific article published in a particular journal and area of knowledge, the productivity of an academic paper and its impact and the average number of weighted citations received in a given year, there is still a gap of indicators that demonstrate publications with significant citations in journals with low impact factor. Another evidence is that such quantitative revelations contribute to an initial decision-making process, but with limitations, since the content of each publication was not analyzed interpretatively.

The main methodological contributions of this work is in revealing that the Impact Factor, H-index, number of citations, and SJR indicators cannot fully demonstrate the scientific relevance of the publications, as we pointed out based on cluster analysis.

The main limitations of this study lie, first, in the research considering only the quantitative indicators, without taking into account the content analysis of the article. At tis point, for future works we suggest the use of scientific indicators associated with an interpretative content analysis of the publications, in order to reveal new scientific evidences on the scientific publications regarding industry 4.0. As suggestions for future research, there is a bibliometric analysis, together with an interpretation of the content of the articles that will provide new evidence

\section{References}

Ancarani, A., Di Mauro, C., \& Mascali, F. (2019). Backshoring strategy and the adoption of Industry 4.0: Evidence from Europe. Journal of World Business, 54(4), 360-371.

Antunes, A. A. (2015). Como avaliar produção científica. Revista do Colégio Brasileiro de Cirurgiões, 42(1), 17-19.

Araújo, C. A. (2006). Bibliometria: Evolução histórica e questões atuais. Em Questão, 12(1), 11-32.

Arbix, G. et al. (2017). O Brasil e a nova onda de manufatura avançada: O que aprender com Alemanha, China e Estados Unidos. Novos Estudos CEBRAP, $36(3), 28-49$.

Basl, J. (2017). Pilot study of readiness of Czech companies to implement the principles of Industry 4.0. Management and Production Engineering Review, $8(2), 3-8$.

Bollen, J., Rodriquez, M. A., \& Van De Sompel, H. (2006). Journal status. Scientometrics, 69(3), 669-687.

Christensen, C. M., Raynor, M. E., \& Mcdonald, R. (2015). What is disruptive innovation. Harvard Business Review, 93(12), 44-53.

Costas, R., \& Bordons, M. (2007). The h-index: Advantages, limitations and its relation with other bibliometric indicators at the micro level. Journal of Informetrics, 1(3), 193-203.

Dellavalle, R. P. et al. (2007). Refining dermatology journal impact factors using PageRank. Journal of the American Academy of Dermatology, 57(1), 116119. 
Dutta, G., Kumar, R., \& Sindhwani, R. (2020). Digital transformation priorities of India's discrete manufacturing SMEs - a conceptual study in perspective of Industry 4.0. Competitiveness Review: An International Business Journal, 30(3), 289-314.

Elkington, J. (1998). Cannibals with Forks. The Triple Bottow Line of 21st Century Business, Grabiola Island: New Society Publishers.

Falagas, M. E., Pitsouni E. I., Malietzis, G. A., \& Pappas, G. (2008). Comparison of PubMed, Scopus, web of science, and Google scholar: strengths and weaknesses. The FASEB journal, 22(2), 338-342.

Garfield, E. (2000). The use of JCR and JPI in measuring short and long term journal impact. Croatian Medical Journal, 41(4), 368-74.

Garfield, E. (2006). The History and Meaning of the Journal Impact Factor. JAMA, 295(1), 90-93.

Gereffi, G. (2013). Global value chains in a post-Washington Consensus world. Review of International Political Economy, 21(1), 9-37.

Gerlitz, L. (2016). Design management as a domain of smart and sustainable enterprise: business modelling for innovation and smart growth in Industry 4.0. The International Journal Entrepreneurship and Sustainability Issues, 3(3), 244-268.

Gobble, M. M. (2014). News and analysis of the globla innovation scene. Research-Technology Management, 57(2), 2-8.

Goffman, W. (1966). Mathematical approach to the spread of scientifics ideas: The history of mast cell research. Nature, 212(1), 449-452.

González-Pereira, B., Guerrero-Bote, V. P., \& Moya-Anegón, F. (2010). A new approach to the metric of journals' scientific prestige: The SJR indicator. Journal of Informetrics, 4(3), 379-391.

Hair, J. F. et al. (2009). Análise multivariada de dados. 6. ed. Porto Alegre: Bookman.

Hartmann, M., \& Halecker, B. (2015). Management of innovation in the industrial internet of things. In: Proc. 26th Int. Society for Professional Innovation Management Conf. (ISPIM), pp. 1-17. Budapest.

Hirsch, J. E. (2005). Na index to quantify na individual's scientific research output. Proceedings of the National Academy of Sciences, 102(46), 16569-16572.

Instituto de Estudos para o Desenvolvimento Industrial - IEDI. (2017). Política Industrial para o futuro - A iniciativa indústria 4.0 na Alemanha. IEDI. Recuperado de: https://www.iedi.org.br/cartas/carta_iedi_n_807.html.

Kagermann, H., Wahlster, W., \& Helbig, J. (2013). Recommendations for implementing the strategic initiative INDUSTRIE 4.0: Securing the future of German manufacturing industry; final report of the Industrie 4.0 Working Group. Forschungsunion.

Khan, M. et al. (2017). Big data challenges and opportunities in the hype of Industry 4.0. In: 2017 IEEE International Conference on Communications (ICC). IEEE, p. 1-6.

Kiel, D., Müller, J. M., Arnold, C., \& Voigt, K. (2017). Sustainable industrial value creation: Benefits and challenges of industry 4.0. International Journal of Innovation Management, 1(8), 1-34

Kim, D. (2020). Electronic Commerce Research and Applications A 2020 perspective on "A dynamic model for the evolution of the next generation Internet Implications for network policies": Towards a balanced perspective on the Internet 's role in the 5G and Industry 4.0. Electronic Commerce Research and Applications, 41, e100966.

Kodrzycki, Y. K., \& Yu, P. (2006). New approaches to ranking economics journals. The BE Journal of Economic Analysis \& Policy, 5(1), 5-12.

Lee, E. A. (2008). Cyber physical systems: Design challenges. 11th IEEE International Symposium on Object and Component-Oriented Real-Time Distributed Computing (ISORC).

Li, L. (2018). China's manufacturing locus in 2025: With a comparison of "Made-in-China" and "Industry 4.0". Technological Forecasting \& Social Change, $135,66-74$

Li, L. (2013). The path to Made-in-China: How this was done and future prospects. International Journal of Production Economics, 146(1), 4-13.

Morteza, G. (2018). The future of manufacturing industry: A strategic roadmap toward Industry 4.0. Journal of Manufacturing Technology Management, 29(6), 910-936.

Mueller, S. P. M. (2006). A comunicação científica e o movimento de acesso livre ao conhecimento. Ciência Da Informação, 35(2), 27-38.

Okubo, Y. (1997). Bibliometric indicators and analysis of research systems: Methods and Examples. OECD Science, Technology and Industry Working Papers, No. 1997/01, OECD Publishing, Paris.

Panés, J., \& Gisbert, J. P. (2009). Publicación científica, indicadores bibliométricos e índice h de Hirsch. Gastroenterología y hepatología, 32(3), 140-149.

Price, D. J. S. (1695). Networks of scientific papers. Science, 149(3683), 510-515.

Quindós, G. (2009). Confundiendo al confuso: Reflexiones sobre el factor de impacto, el índice h (irsch), el valor Q y otros cofactores que influyen en la felicidad del investigador. Revista Iberoamericana de Micología, 26(2), 97-102. 
Research, Society and Development, v. 10, n. 11, e193101118923, 2021

(CC BY 4.0) | ISSN 2525-3409 | DOI: http://dx.doi.org/10.33448/rsd-v10i11.18923

Rajkumar, R., Lee, I., Sha, L., \& Stankovic, J. (2010). Cyber-physical systems: the next computing revolution. In: Proceedings of the design automation conference 13-18 June 2010, Anheim, p. 731-736.

Ruiz, M. A., Greco, O. T., \& Braile, D. M. (2009). Fator de impacto: Importância e influência no meio editorial, acadêmico e científico. Revista Brasileira de Hematologia e Hemoterapia, 31(5), 355-360.

Schwab, K. A Quarta Revolução Industrial. São Paulo: Edipro, 2017.

Schwab, K. Aplicando a quarta revolução industrial. São Paulo: Edipro, 2018.

Schwab, K. (2018). The Global Competitiveness Report. Fórum Econômico Mundial. Disponível em: <The World Economic Forum (weforum.org)>

Ślusarczyk, B. (2018). Industry 4.0: Are we ready?. Polish Journal of Management Studies, 17(1), 232-248.

Thomaz, P. G., Assad, R. S., \& Moreira, L. F. P. (2011). Uso do fator de impacto e do índice H para avaliar pesquisadores e publicações. Arquivos Brasileiros de Cardiologia, 96(2), 90-93.

Toro, A. G., \& Amezcua, M. (2006). The Hirsch's h-index. An update on the author's evaluation methods and their contributions in scientific publications. Index de Enfermería [Index Enferm], 55, 38-43.

Wang, S., Wan, J., Li, D., \& Zhang, C. (2016). Implementing Smart Factory of Industrie 4.0: An Outlook. International Journal of Distributed Sensor Networks, 12(1), 3159805.

Winkmann, G., Schlutius, S., \& Schweim, H. G. (2002). Citation rates of medical German-language journals in English-language papers-do they correlate with the Impact Factor, and who cites?. DMW - Deutsche Medizinische Wochenschrift, 127(4), 138-143.

Zupic, I.., \& Čater, T. (2015). Bibliometric Methods in Management and Organization. Organizational Research Methods, 18(3), 429-472. 